Arab Univ. J. Agric. Sci., Ain Shams Univ., Cairo, Egypt

28(1), 239-251, 2020

Website: http://ajs.journals.ekb.eg

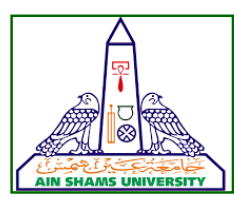

239

\title{
EFFECT OF DIFFERENT SLOW RELEASE POTASSIUM FERTILIZER RATES ON GROWTH AND PRODUCTIVITY OF BANANA CV. WILLIAMS PLANTS
}

\author{
Abo-Hamda ${ }^{*}$ B.T., El-Hennawy ${ }^{2}$ H.M., Abd El-Hamid ${ }^{2}$ A. and \\ Eman A.A. Abd El-Moniem ${ }^{1}$ \\ 1- Horticultural Crops Technology Dept., National Research Centre, 33 Bohouth st., Dokki, Giza, \\ Egypt \\ 2- Horticulture Dept., Fac. of Agric., Ain Shams Univ., P.O. Box 68, Hadayek Shoubra 11241, \\ Cairo, Egypt \\ *Corresponding author: bassamlife@yahoo.com
}

[17]

Received 21 November, 2019

Accepted 31 May, 2020

\begin{abstract}
This study was carried out during the two successive seasons (2017 and 2018) on the first and second ratoon of healthy uniform banana cv. Williams (Musa spp.) Plants grown in sandy soil under drip irrigation system in a private orchard located at El-Tahadi region, Cairo Alexandria desert road, Behaira governorate, Egypt. The investigation aimed to study the effect of different slow release potassium fertilizer (SRKF) $\left(50 \% \mathrm{~K}_{2} \mathrm{O}\right)$ rates $(100 \%$, $75 \%$ and $50 \%$ ) were added as soil drench during mid March, mid June and mid September while, potassium sulphate dose used in control treatment was added at monthly intervals as soil application from mid March until mid October on vegetative growth, productivity, total yield income and net return/feddan of banana plants. The obtained results showed that, all treatments had a significant effect on enhancing the vegetative growth parameters, i.e. number of green leaves /plant, plant total assimilation area ( $\mathrm{m}^{2} /$ plant), leaf total chlorophyll content $(\mathrm{CCl})$ and leaf macro element content $(\mathrm{N}$, $\mathrm{P}$ and $\mathrm{K}$ ) as (\%) as well as leaf micro element content (Fe, $\mathrm{Zn}$ and $\mathrm{Mn}$ ) as (ppm). Also, improving yield (ton/feddan), bunch weight $(\mathrm{kg})$, number of hands/bunch, hand weight $(\mathrm{kg})$, number of fingers/hand, finger weight $(\mathrm{g})$, finger length $(\mathrm{cm})$, finger circumference $(\mathrm{cm})$, finger pulp weight $(\mathrm{g})$, finger pulp/peel (ratio), TSS (\%), TSS/TA (ratio), total sugars (\%). In addition, the total yield income (1000 LE) and net return/feddan (1000 LE) in both seasons. Moreover, all treatments had no significant effect on plant pseudostem height $(\mathrm{cm})$, pseudostem

circumferences $(\mathrm{cm})$ and leaf area $\left(\mathrm{m}^{2}\right)$ of plant in both seasons and bunch length $(\mathrm{cm})$ in the first season only. Treatment of: slow release potassium at $100 \%$ gave the highest values of physical and chemical properties of banana plants $\mathrm{cv}$. Williams in both seasons compared to, control treatment $(100 \%$ potassium sulphate) and slow release potassium at $50 \%$ gave the lowest values.

Keywords: Banana, Slow release potassium, Growth, Productivity

\section{INTRODUCTION}

In Egypt, banana plants are considered as the $4^{\text {th }}$ largest fruit crops as total cultivated area, following citrus, grapes and mango. The total area of banana increased up to 82000 feddan, producing $1,365,000$ tons with average of 16.646 tons/feddan according to the statistics of Egyptian, Ministry of Agriculture and Land Reclamation (Bulletin of the Agricultural Statistics, 2017).

Williams banana is one of the giant Cavendish type in the Cavendish subgroup. It is cultivated successfully in the new reclaimed soils because of its excellent performance, and high tolerance to transportation (Vezina, 2017).

Banana plants need a large amount of fertilization elements especially potassium (Kumar and Kumar, 2008b). Moreover, it draws nutrients from a very limited soil depth due to its shallow root system, in addition, high water requirements which cause a great leaching of most applied elements, particularly potassium (Mendes et al 2016 and Godoy et al 2018).
\end{abstract}


Potassium $(\mathrm{K})$ has many roles in the plants particularly banana such as photosynthesis regulation, protein and starch synthesis, enzyme activities (at least 60 different enzymes) (Marschner, 1995). It plays a major role in the transport of sugar and nutrients through the phloem to other parts of the plant for utilization and storage. Its effect mainly depends on the method, level and the source of application (Tuner and Barkus, 1983; Mengel and Kirkby, 1987; Ram and Prasad, 1988; Borges, 2004; Kumar and Kumar, 2008a; Patel et al 2017 and Millik et al 2018). Mineral potassium became a high expensive fertilizer in Egypt, besides; the excessive uses of chemical fertilizers have resulted in serious problems, i.e. soil salinity, pollution of the underground water.

The application of slow release potassium fertilizers was developed mainly to reduce the number of replications per year (Zekri and Koo, 1991) minimize the cost of production, and improve the efficiency of (K) used by trees (Shaviv et al 1997). The control and continues providing of the trees with their requirements of $\mathrm{K}$ can be achieved using slow and controlled release potassium fertilizers which are responsible for releasing their own $(K)$ at a longer period and a critical date of fruit development (George and Robert, 1996; Bettage and Ben
Moimoun, 2010; Oliveira et al 2012; Oliveira et al 2013; Soti et al 2015; $\mathrm{Ng}$ et al 2016 and Godoy et al 2018).

Therefore, this study aimed to investigate the effect of different slow release potassium fertilizer rates on vegetative growth, leaf chemical contents, productivity, fruit physic-chemical characteristics, yield income and net return/feddan of Williams banana plants under sandy soil conditions.

\section{MATERIALS AND METHODS}

Thirty six healthy uniform plants of banana Williams cultivar (Musa spp.) grown in sandy soil under drip irrigation system in a private orchard located at El-Tahadi region, Cairo Alexandria desert road, Behaira governorate, Egypt. Suckers planted as distance of $(3.5 \times 3)$ meters apart, each hole content two suckers (800plants/feddan) and selected during the two successive seasons 2017 (first ratoon plants) and 2018 (second ratoon plants). The soil samples were collected from different locations in the plantation at $0-30$ and $30-60 \mathrm{~cm}$ depths then analyzed for physical and chemical properties. Experimental soil texture and deficient

Fertility according to mechanical and chemical analysis shown in Table (1).

Table 1. Physical and chemical properties of banana plantation soil at the beginning of the experiment.

\begin{tabular}{|c|c|c|c|c|c|}
\hline \multirow{2}{*}{ Physical Properties } & \multicolumn{2}{|c|}{ Soil depth (cm) } & \multirow{2}{*}{ Chemical Properties } & \multicolumn{2}{c|}{ Soil depth (cm) } \\
\cline { 2 - 3 } & $\mathbf{0 - 3 0}$ & $\mathbf{3 0 - 6 0}$ & & $\mathbf{0 - 3 0}$ & $\mathbf{3 0 - 6 0}$ \\
\hline Coarse sand (\%) & 48.70 & 49.00 & $\mathrm{CaCO}_{3} \%$ & 1.20 & 1.40 \\
Fine sand (\%) & 36.30 & 36.20 & $\mathrm{Na}(\mathrm{mg} / \mathrm{L})$ & 2.97 & 3.83 \\
Silt (\%) & 10.40 & 10.30 & $\mathrm{~K}(\mathrm{mg} / \mathrm{L})$ & 0.30 & 0.90 \\
Clay (\%) & 4.60 & 4.50 & $\mathrm{Ca}(\mathrm{mg} / \mathrm{L})$ & 2.16 & 2.30 \\
Texture class & sandy & sandy & $\mathrm{Mg}(\mathrm{mg} / \mathrm{L})$ & 0.92 & 1.10 \\
Organic matter (\%) & 0.40 & 0.35 & $\mathrm{HCO}(\mathrm{mg} / \mathrm{L})$ & 3.50 & 3.88 \\
PH & 8.3 & 8.8 & $\mathrm{Cl}_{(\mathrm{mg} / \mathrm{L})}$ & 2.00 & 3.10 \\
EC (ds/m) & 0.85 & 1.10 & $\mathrm{SO}_{4}(\mathrm{mg} / \mathrm{L})$ & 0.85 & 1.15 \\
\hline
\end{tabular}

This experiment included six fertilization treatments (added as soil drench) as follow:

T1: Control (100\%) potassium sulphate /plant/year $(1.6 \mathrm{~kg})$.

T2: (100\%) slow release potassium/plant/year (1.6 $\mathrm{kg})$.
T3: (75 \%) slow release potassium/ plant/year (1.2 $\mathrm{kg})$.

T4: (75\%) slow release potassium $(1.2 \mathrm{~kg})+(25 \%)$ potassium sulphate/plant/year (400 g).

T5: (50\%) slow release potassium/plant/year (800 g). 
T6: $(50 \%)$ slow release potassium $(800 \mathrm{~g})+(50 \%)$ potassium sulphate/plant/year $(800 \mathrm{~g})$.

Slow release potassium fertilizer $\left(50 \% \mathrm{~K}_{2} \mathrm{O}\right)$ doses were added during mid-March, mid-June and mid-September. While, potassium sulphate doses were added at monthly intervals from mid-March until mid-October through the two seasons of the study according to (Saad, 2001). Each treatment contained three replicates and each replicate had two plants. The following characteristics were estimated.

\section{Vegetative growth parameters}

After the inflorescences emergence (mid-September), the following vegetative characteristics were determined as follows:

1.1. Pseudostem height $(\mathrm{cm})$ : from the soil surface

to junction of the first leaf.

1.2. Pseudostem circumference $(\mathrm{cm})$ : at $20 \mathrm{~cm}$ above soil surface.

1.3. Leaf area $\left(\mathrm{m}^{2}\right)$ : on the third expanded leaf from the top using the following equation:

Leaf area $\left(\mathrm{m}^{2}\right)=$ length $\mathrm{x}$ width $\mathrm{x}$ area coefficient, area coefficient of Williams banana $=0.86$ according to (Obiefuna and Ndubizu, 1979).

1.4. Leaves number per plant at bunch shooting.

1.5. Total assimilation area ( $\mathrm{m}^{2} /$ plant) was determined using the equation: Total assimilation area $\left(\mathrm{m}^{2} /\right.$ plant $)=$ leaf area $\mathrm{x}$ number of green leaves per plant (Ibrahim, 1993).

\section{Leaf chemical contents}

Leaf samples sized $10 \times 10 \mathrm{~cm}$ were taken from the middle part of the blade of the third leaf from from the top of the plant as recommended by (Hewitt, 1955) for mineral analysis. The collected leaf samples were dried in the oven at $70^{\circ} \mathrm{C}$ until constant weight. The dry matter was finely grinded and wet digested with a mixture of concentrated sulfuric acid and perchloric acid $(2: 1)(\mathrm{v} / \mathrm{v})$ for 15 minutes until the digestive solution became colorless and then transferred quantitatively to $50 \mathrm{ml}$ volumetric flask. The considered mineral nutrients were determined in dry matter as follows:

\subsection{Leaf macro elements content}

Total nitrogen content in leaf (\%) was colorimetrically determined using microkjeldahl methods according to the method described by (Pregl, 1945).
Also, phosphorus leaf content (\%) was determined by using spectrophotometer (CECIL CE2040) according to the method advocated by (Champman and Pratt, 1978). In addition, potassium leaf content $(\%)$ was determined by using flame photometer (JENWAY PFP7) according to the method advocated by (Brown and Lilleland, 1946).

\subsection{Leaf micro elements content}

Micro- nutrients (Fe, $\mathrm{Zn}$ and $\mathrm{Mn}$ ) as ppm were determined in the digestive solution using Atomic absorption spectrophotometer Jaril-Ash 850according to (A.O.A.C., 1995).

\subsection{Leaf total chlorophyll content}

Fresh leaf samples were taken from the third upper leaf of the plant top at shooting stage in (midSeptember) of each season to determine leaf total chlorophyll content index (CCI) using CCM-200 plus OPTI-SCIENCES chlorophyll content meter .

\section{Yield and fruit physical characteristics}

Bunches were harvested at the green maturity stage (mid-Jun) then ripened by ethylene method for $24-48$ hours at $15-20^{\circ} \mathrm{C}$ and $90-95 \%$ relative humidity (Kader, 2005). Two hands were taken from the bunch after maturity characteristics (fifth ripening color stage) to estimate the following fruit physical and chemical characteristics for each treatment as follows:

Bunch weight $(\mathrm{kg})$, hand number/bunch, hand weight $(\mathrm{kg})$, finger weight $(\mathrm{g})$, finger pulp weight $(\mathrm{g})$, finger peel weight $(\mathrm{g})$, finger pulp/peel ratio(estimated by divining finger pulp weight by finger peel weight), bunch length (cm), finger length and circumference $(\mathrm{cm})$.

\section{Fruit chemical content}

Total soluble solids (TSS \%) were determined in the pulp juice using a digital refractometer according to (A.O.A.C., 1995). Total titratable acidity (TA\%) as malic acid in the pulp juice was determined by titration with $0.1 \mathrm{~N}$ of $\mathrm{NaOH}$ solution using phenolphethalein (1\%) as an indicator according to (A.O.A.C., 1995), TSS/TA ratio (calculated by divining TSS by TA) and total sugars were determined according to the method described by (Dubios et al 1956). 


\section{Total yield income and net return/feddan (1000 LE)}

Total yield income and net return/feddan (1000LE) were estimated using the economic data of williams fruit as follows: ton unit (5000 LE), total production cost/feddan in the first season $[(70$, 72.65, 68.55, 71.92, 64.72 and 71.28(1000 LE)]and total production cost/feddanin the second season[ $(80,82.65,78.55,81.92,74.72$ and 81.28) (1000 LE)] to all treatments respectively.

5.1. Total yield income/feddan/year (1000 LE): was estimated using the equation: Total yield income $=$ net yield $x$ ton price (1000LE).

5.2. Net return/feddan (1000 LE): was estimated using the equation: Net return/feddan = total yield income - total production cost (1000 LE).

\section{Experimental design and statistical analysis}

The experiment was designed as a randomized complete block design (RCBD), with one factor. The obtained data were tabulated and subjected to analysis of variance (ANOVA) according to (Snedecor and Cochran, 1990). Means of results were compared using the method of Duncan's at $0.05 \%$ level (Duncan, 1955).

\section{RESULTS AND DISCUSSION}

Pseudostem height (cm), no. of green leaves/ plant and pseudostem circumference $(\mathrm{cm})$

Data in Table (2), showed that, all vegetative growth of Williams banana plants i.e., pseudostem height, and pseudostem circumference were not significantly affected by treatments, although a slight increase was detected in all treatments compared to control in both seasons. Whereas, green leaves number was greatly affected by the studied slow release fertilizer treatments in (2017 and 2018) seasons. However, the highest number of green leaves/plant (14.17) was recorded by $100 \%$ slow release potassium in the first season, but the highest values (14.83) was recorded by $75 \%$ slow release potassium $+25 \%$ potassium sulphate in the second season. On the other hand, the lowest values of this parameter was scored by $50 \%$ slow release potassium, compared with control treatment $100 \%$ potassium sulphate in both seasons, respectively. The highest number of green leaves/plant may be due to the continues of supply plants by $\mathrm{K}$ ions from slow release potassium fertilizer (SRKF), its activates at least (60) different enzymes such as (RuBP carboxylase enzyme) and enhances protein content involved in plant growth (Marschner, 1995). These findings are in accordance with those obtained by Felisberto et al 2010; Oliveira et al 2013; Soti et al 2015.

Leaf chlorophyll content $(\mathrm{CCl})$, leaf area $\left(\mathrm{m}^{2}\right)$ and total assimilation area $\left(\mathrm{m}^{2}\right)$

Leaf chlorophyll content $(\mathrm{CCl})$ and total assimilation area $\left(\mathrm{m}^{2}\right)$ of Williams banana plants were positively responded to the studied treatments in shown in Table (3), the highest leaf chlorophyll (50.28 and 53.90$)(\mathrm{CCl})$, and total assimilation area (27.63 and $29.19 \mathrm{~m}^{2} /$ plant) were recorded by $100 \%$ slow release potassium in the two seasons, respectively. In reverse, the lowest values were scored by control treatment. Whereas, leaf area was not significantly affected by treatments, although a slight increase was detected by all treatments than the control in the two seasons. The increase of leaf chlorophyll $(\mathrm{CCl})$ may be due to the potassium has also a role in synthesizing the precursor of cholorophyll pigment and photosynthetic efficiency (Marschner, 1995). The higher values of total assimilation area ( $\mathrm{m}^{2} /$ plant) can be explained by the relation with the increment green leaves number/plant. The illustrated results were in agreement with Felisberto et al 2010; Oliveira et al 2013; Soti et al 2015, $\mathrm{Ng}$ et al 2016 and Godoy et al 2018.

\section{Leaf macro elements content (N, P and $\mathrm{K} \%$ )}

Data presented in Table (4), revealed that, leaf $\mathrm{N}, \mathrm{P}$ and $\mathrm{K}$ content were responded to the tested slow release potassium treatments in both seasons. However, the highest leaf $\mathrm{N}(2.08$ and $3.29 \%), \mathrm{P}$ $(0.35$ and $0.53 \%)$ and $\mathrm{K}(5.20$ and $5.25 \%)$ were recorded by the treatment of $100 \%$ slow release potassium in both seasons, respectively. Inreverse, control treatment $100 \%$ potassium sulphate scored the lowest values of these parameters in the two seasons. (Tuner and Barkus, 1983) explained the role of potassium in promoting $\mathrm{N}, \mathrm{P}$ and $\mathrm{K}$ nutrients content in leaves due to the higher nutrient uptake and better transfer to the xylem. These results are in harmony with those of $\mathbf{~} \mathrm{gg}$ et al 2016. 

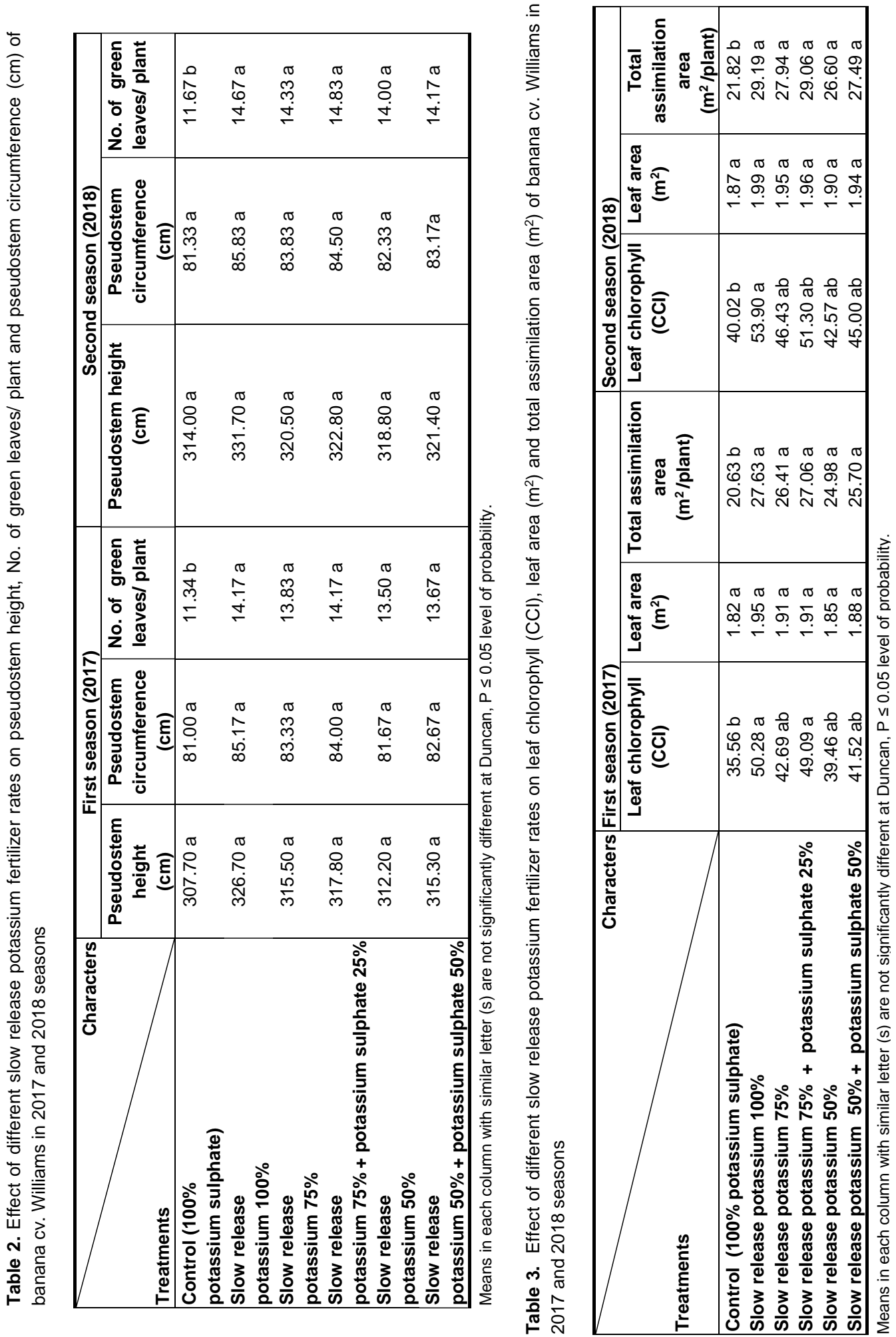


\section{Leaf micro elements content (Fe, $\mathrm{Zn}$ and $\mathrm{Mn}$ as ppm)}

Data listed in Table (5), indicated that, leaf content of $\mathrm{Fe}, \mathrm{Zn}$ and $\mathrm{Mn}$ expressed as (ppm) were significantly affected by slow release potassium treatments in both seasons. The highest leaf values of Fe (350.10 and 353.20 ppm), Zn (33.37 and35.57 ppm) and $\mathrm{Mn}$ (358.30 and 359.00 ppm) were recorded by $100 \%$ slow release potassium in both seasons, respectively. In counter, control treatment $100 \%$ potassium sulphate scored the lowest values of these parameters in the two seasons. The leaves higher $\mathrm{Fe}, \mathrm{Zn}$ and $\mathrm{Mn}$ contents may be due to the role of potassium in increase the nutrients absorption through the xylem (Tuner and Barkus, 1983).

Yield (ton/feddan), bunch weight (kg), and bunch length $(\mathrm{cm})$

Results given in Table (6), pointed out that, the highest yield (26.18 and 28.10 ton/feddan) and bunch weights (32.73 and $35.13 \mathrm{~kg}$ ) were recorded by $100 \%$ slow release potassium in the first and second seasons, respectively. In addition, the bunch length was not significantly affected by all treatments in the first season, whereas, in the second season; the tallest bunch ( 91.67 and $94.67 \mathrm{~cm}$ ) was recorded by slow release potassium at $100 \%$. In reverse, control treatment $100 \%$ potassium sulphate scored the lowest values of these parameters in both seasons, respectively. The increase in bunch weight was also associated with the corresponding significant increase in the number of hands, number of fingers and finger weight. Beside, the increase of yield was related to the increase in the bunch weight (Kumar and Kumar, 2008 a). These results are in agreement with the results obtained by George, and Robert, 1996; Oliveira et al 2012; Oliveira et al 2013; $\mathrm{Ng}$ et al 2016 and Godoy et al 2018 .

No. of hands/bunch, no. of fingers/hand and hand weight $(\mathbf{k g})$

The effect of different slow release potassium fertilizer treatments on no. of hands/bunch, no. of fingers/hand and hand weight $(\mathrm{kg})$ were presented in Table (7), the data clearly indicated that, the highest number of hands /bunch (11.17 and 11.33 hands) number of fingers/ hand (17.33 and 17.83 fingers) and the heaviest hand $(2.44$ and $2.58 \mathrm{~kg})$ were recorded by treatment of slow release potassium $100 \%$ in both seasons, respectively. Compared with control treatment. However, the highest values of hand weigh $(\mathrm{kg})$ (2.44 and 2.58) were recorded by $100 \%$ slow release potassium in both seasons, respectively. In reverse, the lowest values of these parameters were registered by control treatment at conc. $100 \%$ of potassium sulphate in both seasons. The highest no. of hands/ bunch, no. of fingers / hand and hand weight may be due to the role of potassium in increase the translocation of carbohydrates from the leaves to fruits (Borges, 2004). The obtained results were in agreement with finding of Oliveira et al 2012; Oliveira et al 2013; $\mathrm{Ng}$ et al 2016 and Godoy et al 2018.

Finger weight (g), finger length (cm), finger circumference $(\mathrm{cm})$

Data in Table (8), cleared that, the heaviest finger ( 141.00 and $145.00 \mathrm{~g}$ ), the highest values of finger length $(20.51$ and $20.63 \mathrm{~cm})$ and finger circumference $(11.70$ and $11.72 \mathrm{~cm}$ ) were corded by $100 \%$ slow release potassium in both seasons. On the other hand, the lowest values were registered by control treatment $100 \%$ potassium sulphate in the two seasons, respectively. Higher finger weight was associated with increase of finger pulp weight as in table (9). In addition, the increase of finger length and finger circumference clearly indicated that potassium was involved in cell enlargement and the increase of finger circumference might be due to the constant potassium supply from (SRKF) which acted as an activator of several enzymes (Millik et al 2018). The results are confirmed by those obtained of Oliveira et al 2012; Oliveira et al 2013; $\mathrm{Ng}$ et al 2016 and Godoy et al 2018.

\section{Finger pulp weight (g), finger peel weight (g) and} pulp/peel (ratio)

Finger pulp weight and pulp/peel ratio were significantly affected by slow release potassium fertilizer treatments during the study in as shown in Table (9), fertilized plants by $100 \%$ slow release potassium significantly gave the highest finger pulp weight (105.80 and $112.80 \mathrm{~g}$ ) and pulp/peel ratio (3.00 and $3.50 \%$ ) in the two seasons, respectively compared to control treatment. On the other hand, control treatment $100 \%$ potassium sulphate scored the lowest value of finger peel weight $(\mathrm{g})$ in the first 

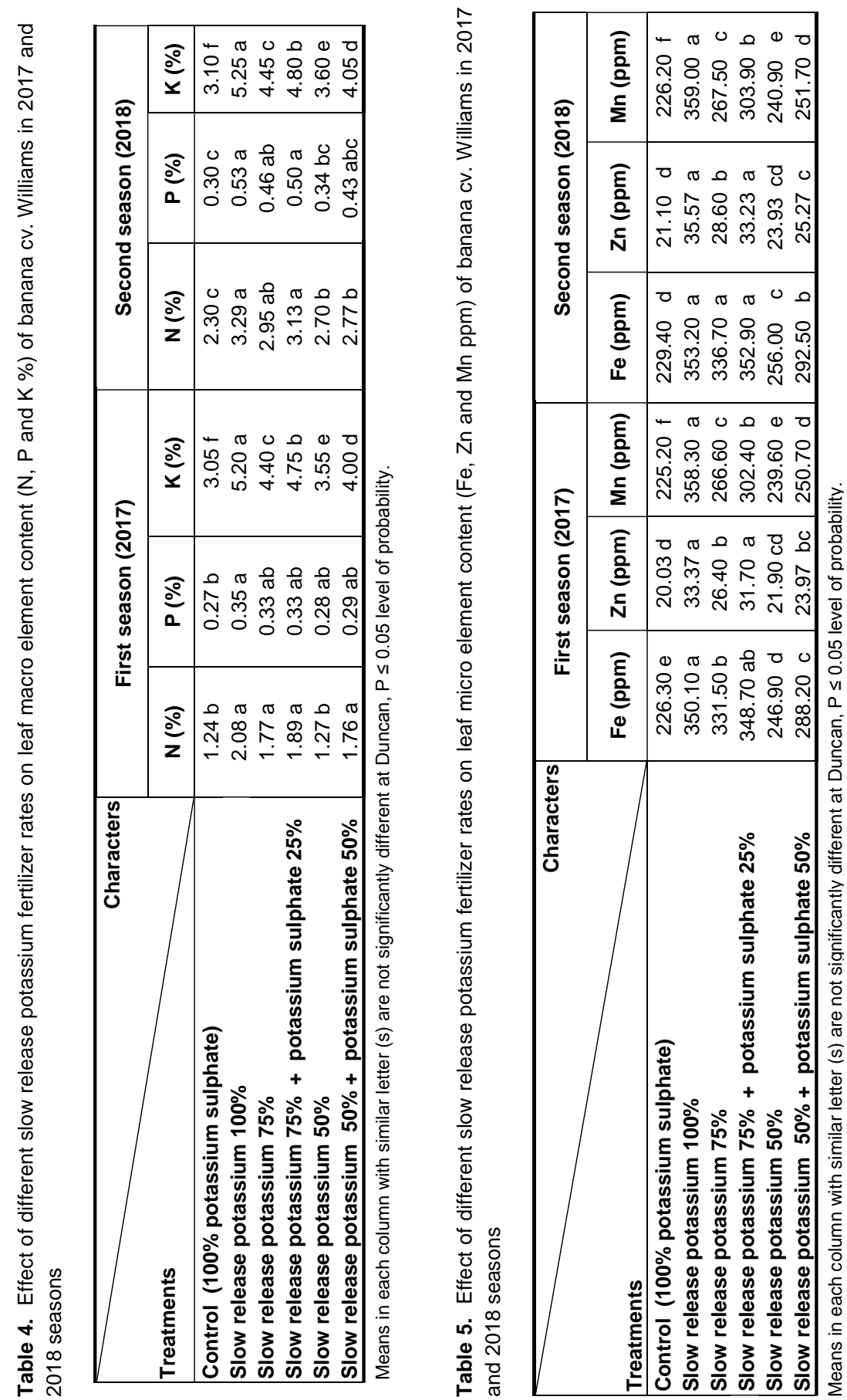

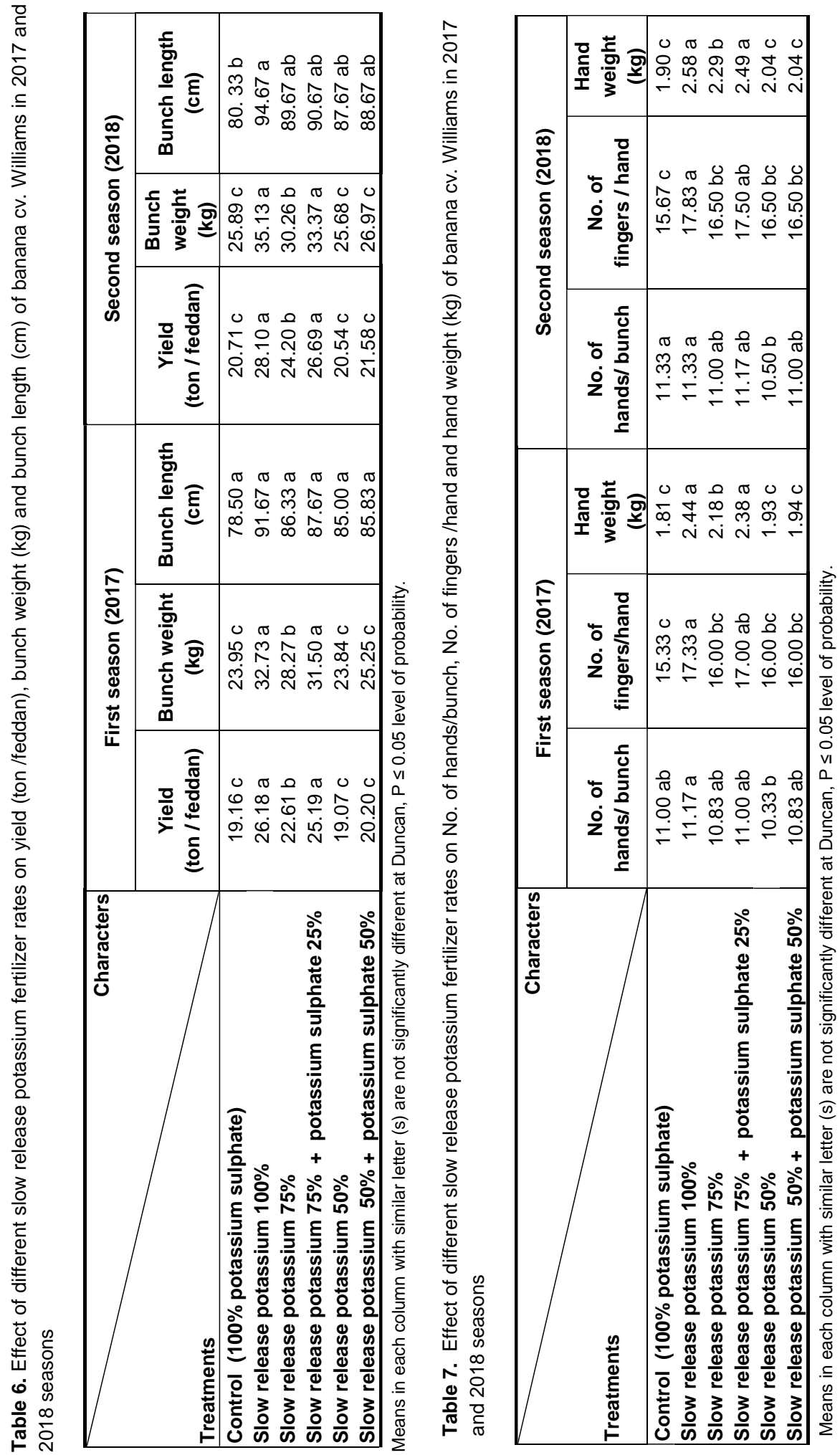

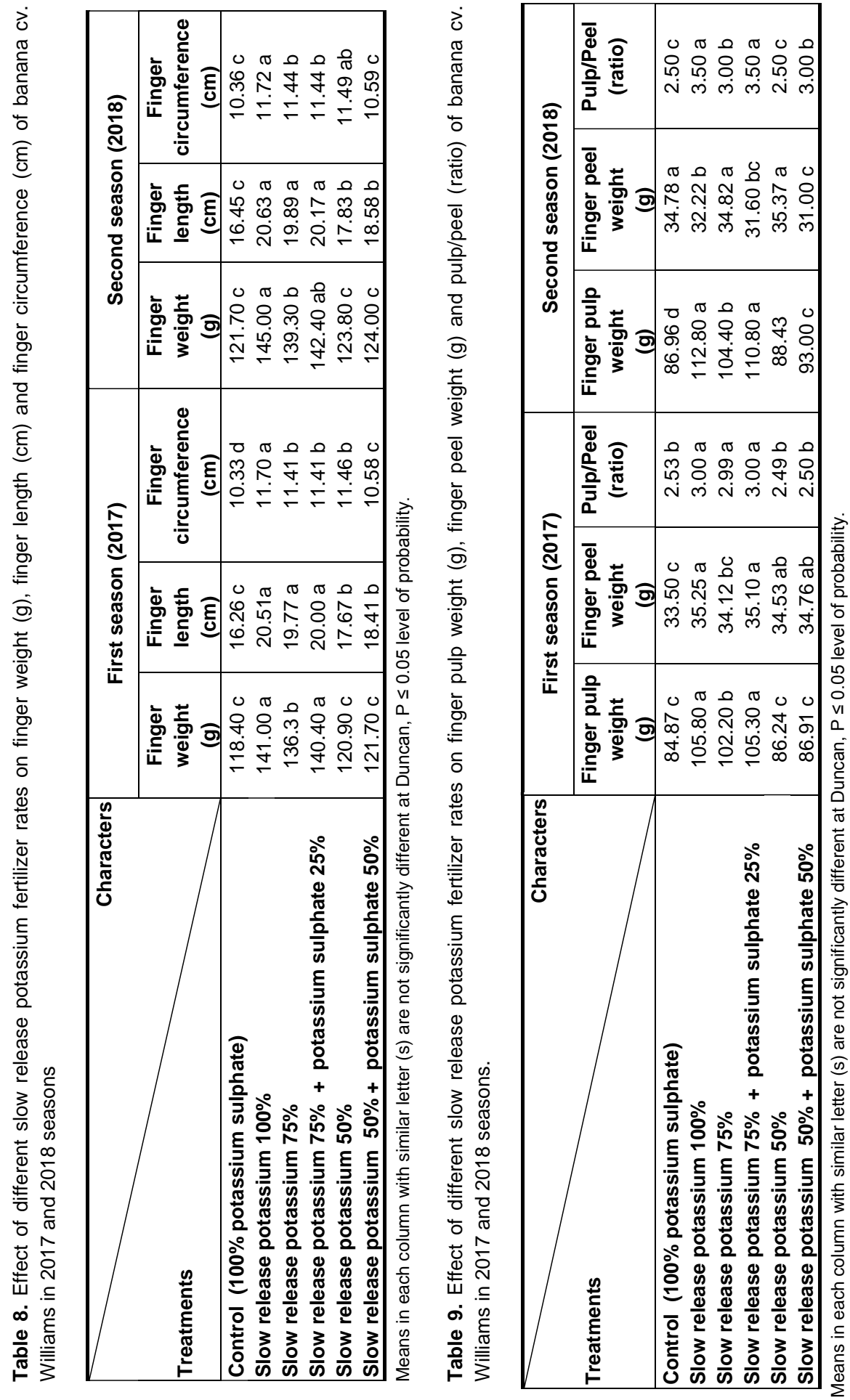

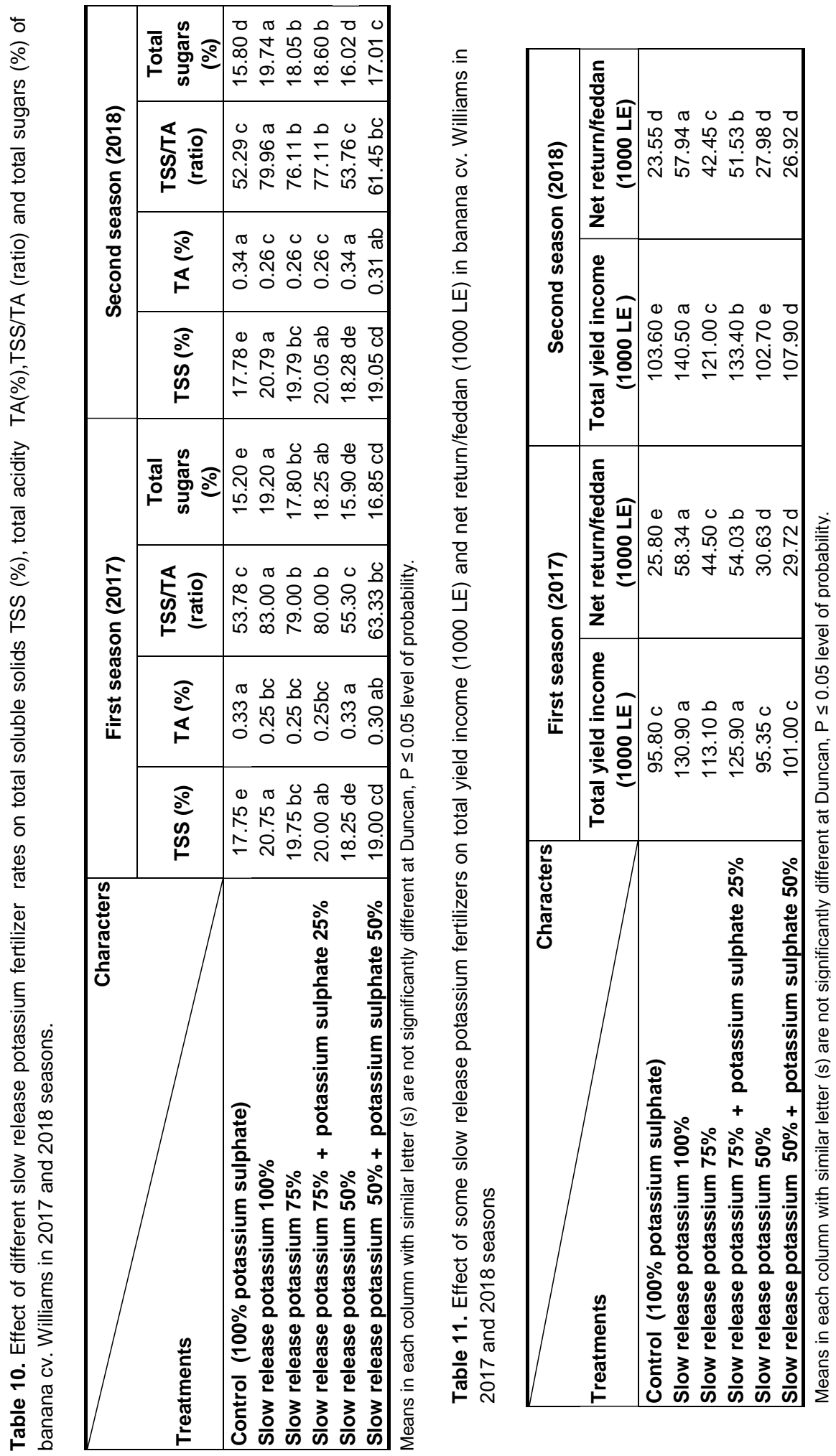
season but, $50 \%$ slow release potassium $+50 \%$ potassium sulphate gave the lowest value in the second season. The increase in pulp/peel ratio by the higher supply of potassium was mainly due to the increase in pulp weigh which was the consequence of satisfactory activity of the enzymes involved in starch and protein synthesis (Patel et al 2017). These results were in harmony with Bettage and Ben Mimoun 2010; Oliveira et al 2012; Oliveira, et al 2013; $\mathrm{Ng}$ et al 2016.

Total soluble solids (TSS \%), total acidity (TA \%), TSS/TA (ratio) and total sugars (\%)

Results given in Table (10), during the two successive seasons revealed that, the highest values of fruits TSS (20.75 and $20.79 \%)$, TSS/TA (83.00 and $79.96 \%$ ) and total sugars (19.20 and $19.74 \%$ ) were recorded by $100 \%$ slow release potassium during the two seasons, respectively. On the other hand, the lowest values were registered by control treatment $100 \%$ potassium sulphate in the two seasons. Whereas, total acidity parameter registered the highest values $(0.33$ and $0.34 \%$ ) by $50 \%$ slow release potassium and control treatments in both seasons, respectively. The Increase in TSS may be due to respiration demand and adequate supply of nutrients, synthesis of inverters and starch splitting enzyme (Ram and Prasad, 1988). The higher sugar content can be explained by the role of potassium in activating the enzymes of starch breakdown during banana ripening such as (sucrose synthase and sucrose phosphate synthase enzymes) (Mengel and Kirkby, 1987; Cordenunsi and Lajolo, 1995). The finding data were in agreement with $\mathbf{~} \mathrm{g}$ et al 2016.

Total yield income (1000 LE) and net return/feddan (1000 LE)

Data presented in Table (11), showed that, the highest values of total yield income/feddan (130.90 and $140.50 / 1000$ LE) and net return /feddan (58.34 and 57.94 / 1000 LE) were recorded by $100 \%$ slow release potassium in both seasons, respectively. While, control treatment $100 \%$ potassium sulphate and treatment $50 \%$ slow release potassium scored the lowest values in both seasons. The increase of total yield income was also associated with the significant increase in the net yield. In addition, the increment of netreturn/feddan was related to the increase in total yield income. The results agreed with repoted finding of Felisberto et al 2010 and $\mathbf{~ N g}$ et al 2016.

\section{CONCLUSION AND RECOMMENDATION}

From this study, it could be recommended that, Williams banana plants fertilized with $100 \%$ slow release potassium recorded the highest values of yield (ton/feddan) and net return /feddan (1000 LE), also, enhanced quality of Williams fruits, i.e. TSS (\%) and total sugars (\%) under the same conditions of this study in 2017 and 2018 seasons.

\section{REFERENCES}

A.O.A.C Association of Official Agricultural Chemists 1995. Official Methods of Analysis of A.O.A.C., pub. by A.O.A.C. Chapter (4) pp. 1820; (37) p. 10; (44) pp. 8-9. International suite 4002200 Wilson Boulevard Arlington, Virginia 22201-3301, USA.

Bettage N. and BenMimoun M. 2010. Effects of controlled-release fertilizer on fruit yield and quality of Celementine citrus trees. VI International Symposium on Mineral Nutrition of Fruit Crops. Acta Hortic, 868, 429-432.

Borges A. 2004. Calagem e adubacao. In: Borges, A. and Souza L., L.S. (Eds.). O cultivo da bananeira. Cruz das almas: EMBRAPA. pp. 32-43.

Brown J. and Lilleland O. 1946. Rapid determination of potassium and sodium in plant material and soil extract by flame photometry. Proc. Amer. Hort. Soc. Sci., 48, 341-346.

Bulletin of the Agricultural Statistics, 2017. Ministry of Agric. and land Reclamation, A.R.E., acreage and total production of fruits, (in Arabic), $170 \mathrm{p}$.

Champman H. and Pratt P. 1978. Methods of Analysis for Soils, Plants and Water. $6^{\text {th }}$ Davis Agric. Sci. Pull Office Calif. Univ., USA. pp. 56-64.

Cordenunsi D. and Lajoli F. 1993. Starch breakdown during banana ripening: sucrose synthase and sucrose phosphate synthase. J. of Agri. Food Chem., 43, 347-351.

Dubois M., Gilles K., Hamilton J., Rebers P. and Smith F. 1956. Colorimetric method for determination of sugars and related substances. AnaIytical Chemistry. 28(3), 350-356.

Duncan D. 1955 . Multiple ranges and multiple $F$ tests. Biometrics, 11, 1-42.

Felisberto G., Godoy L., Albanaz A., Furuya F., Franca F. and Fehr R. 2010. Crescimento de Bananeira sob doses de fertilizantepotassico de 
liberacaocontrolada e convencional.xxxIII, CongressoBrasileiro de Ciencia do Solo. pp. 1-4.

George H. and Robert H. 1996. Effects K rate and proportion of $\mathrm{K}$ supplied from controlled - release K on Pepper. Research report Suwannee valley Research and Education Center. University of Florida, live Oak. USA. pp. 1- 10.

Godoy L., Souza C., Borba M., Kabata R., Bortolini G. and Reschini B. 2018. Controlled release fertilizer in the first production cycle of the banana crop. $21^{\text {th }}$ World Congress of Soil Sci., Rio de Janeiro, Brazil, pp. 908-914.

Hewitt C. 1955. Leaf analysis as a guide to the nutrition of banana. Emp J. Exp. Agric., 23, 1116.

Ibrahim E. 1993. Studies on irrigation of banana. Ph.D. Thesis, Fac. of Agric. Zagazig Univ. Zagazig, Egypt, 52 p.

Kader A. 2005. Banana-recommendations for maintaining postharvest quality. http://postharvest. Ecdavis. Edu/Produce/Produce Facts/Fruit/Full banana ripening.

Kumar A. and Kumar N. 2008 a. Studies on the efficacy of sulphate of potash (SOP) on the physiological, yield and quality parameters of banana cv. Robusta (Cavendish-AAA). Eur. Asian J. of Bio. Sci., 2(12), 102-109.

Kumar A. and Kumar N. 2008 b. A review: Potassium nutrition in banana. Asian J. of Hort., 3(2), 479-482.

Marschner H. 1995. Mineral nutrition of higher plants. $2^{\text {nd }}$ ed. Academic press, London, USA. pp. 300-304.

Mendes W. Junior J., Cunha P., Silva A., Evangelista A. and Casaroli D. 2016. Potassium leaching in different soils as a function of irrigation depths. Revista Brasileira de Engenharia Agricola e Ambiental, 20(11), 972-977.

Mengel K. and Kirkby E. 1987. Principles of plant nutrition. $4^{\text {th }}$ ed. International Potash Institute, IPI, Bern, Swizerland. 685 p.

Millik T., Baruah K., Kumar V. and Barik N. 2018. Effect of bunch feeding on nitrogen $(\mathrm{N})$ and potassium $(\mathrm{K})$ on yield characters in banana, cv. Barjahaji (Musa AAA group) under Assam condition, India. Current, J. of Applied Sci. and Technol., 26(1), 1-7.

Ng Ch., Wu S.Z., AbdulAziz M. and Tan Y. 2016. Effects of novel slow release fertilizer on Banana foliar nutrients, photosynthetic rate, chlorophyll content, yield and fruit quality. Hans J. of Agric. Sci. 6(3), 49-56.
Obiefuna J. and Ndubizu T. 1979. Estimating leaf area of plantation. Scientia Horticulturae, 11(1), 31-36.

Oliveira F., Godoy L., Felisberto G., Albanaz A., Garotti F., Fehr R., Sousa R. and Furuya F. 2012 Produtividade da Bananeira e teores de potassio e enxofre no solo sob doses de fertilizantepotassico de liberacaocontrolada e convencional. Aresponsabilidadesocioambiental da pesquisa Agricola. 17 a 21 de setembro - centro de convencoes- Maceio/alagoas. pp. 1-4.

Oliveira F., godoy L., Alves H., Neto A., Rosa N., and Marcuze A., 2013. Growth and yield of banana plant under controlled-release and conventional potassium fertilizer rates. Xx reuniaointernacional da associacaopara a cooperacaoempesquisa e desenvolvimento integral das musaceas (bananas e platanos) 9 a 13 de setembro.

Patel B., Ahlawat T. and Patel B. 2017. Effect of potash fertilizers and magnesium on quality of banana (Musa paradisiacal L.) cv. Grand Naine. Int. J. of Chemical Studies. 5(4), 1586-1591.

Pregl F. 1945. Quantitative Organic Micro Analysis. 4th Ed. Churchill, Ltd, London, $17 \mathbf{p}$.

Ram R. and Prasad J. 1988. Effect of nitrogen, phosphorus and potassium on fruit quality of banana cv. Campierganj local (Musa ABB). South Indian Horticulture. 36(6), 290-292.

Saad M. 2001. Banana. Tec. Bull No. 6, Extension Department. Ministry of Agriculture, A.R.E., (in Arabic). pp. 21-23.

Shaviv U., Shaviv A., Shalit G. and Zasalaysky D., 1997. Release characteristics of a new control release fertilizer. J. of Controlled Release, 43, 131-138.

Snedecor G. and Cochran W. 1990. Statistical Methods. The lowa State Univ. Press, Amer. lowa: USA. $7^{\text {th }}$ ed. pp. 365-372.

Soti P., Fleurissaint A., Reed S., and Jayachandran K. 2015. Effect of control release fertilizers on nutrient leaching, palm growth and production cost. Agriculture, 5, 1135-1145.

Tuner D. and Barkus B. 1983. The uptake and distribution of mineral nutrients in the banana in response to supply of $\mathrm{K}, \mathrm{Mg}$ and Mn. Ferti. Res., 4, 89-99.

Vezina 2017. Williams (Musa spp.). pp. 1-4. http://www.promusa.org/Williams.

Zekri M. and Koo R. 1991. Evaluation of controlled - release fertilizers for young citrus trees. J. of American Society for Hortic. Sci., 116(6), 987990. 
تأثير معدلات مختلفة من الأسمدة البوتاسية بطيئة التحلل على نمو وانتاجية نباتات الموز صنف وليامز

\author{
بسام طه أبوحمده" "- حسين محمود الحناوى2- أحمد عبدالحميد عوض2--

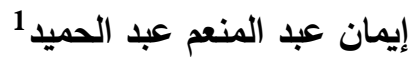 \\ 1- قسم تكنولوجيا الحاصلات البستانية - المركز القومى للبحوث - 33 شارع البحوث - الدقى - الجيزة - مصر عرب \\ 2- قسم البساتين - كلية الزراعة - جامعة عين شمس - ص.ب 68 - حدائق شبرا 11241 - القاهرة - مصر
}

*Corresponding author: bassamlife@yahoo.com

(الطن/الفدان)، وزن السباطة (كجم)، عدد الكفوف فى الكى

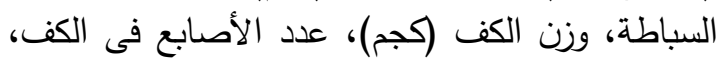

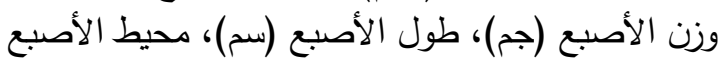

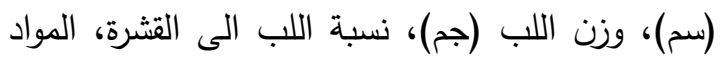

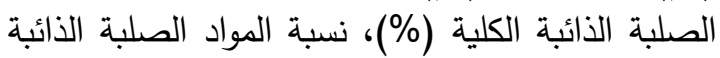

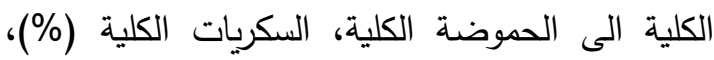

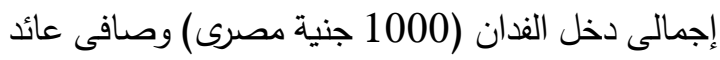
الفدان (1000 جنية مصرى) فى كلا الموسمين المتتاليين. بينما لم تؤثر جميع المعاملات السيات السابقة تأثيرا

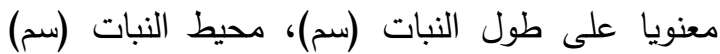

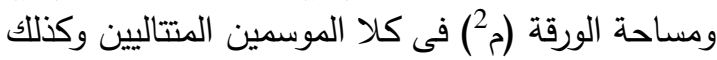

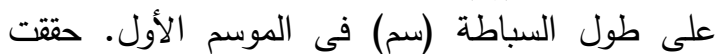

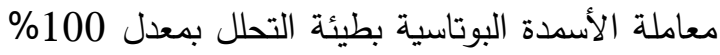

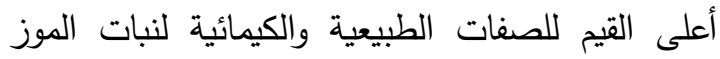
صنف وليامز خلال موسمى الدراسة، مقارنة بمعاملة التانة

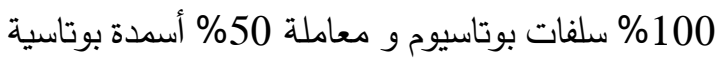

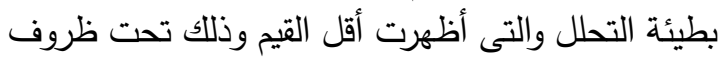
التجربة فى كلا الموسمين المتتاليين.

الإنلمات المفتاحية: الموز ، بوتاسيوم بطئ التحلل، النمو ، الإنتاجية

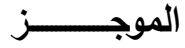

أجريت هذة الدراسة خلال موسمى 2017 2018 2018على الخلفة الأولى والثانية لنباتات الموز صنف التفى وليامز النامية فى أرض رملية تحت نظام الرى بالتتقيط فى مزرعة

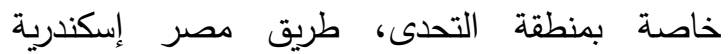

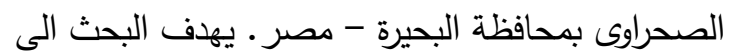

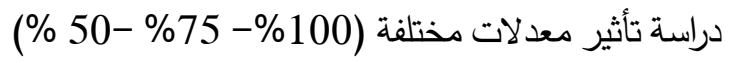

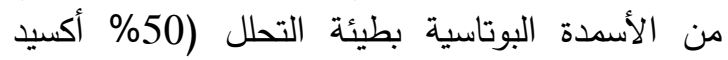

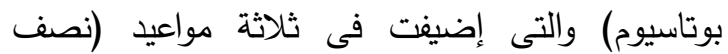
مارس- نصف يونيو - نصف سبتمبر)، بينما إضيف

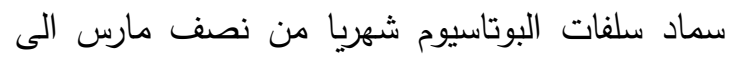

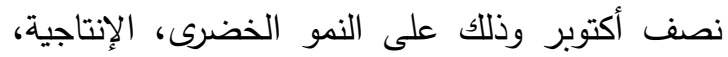

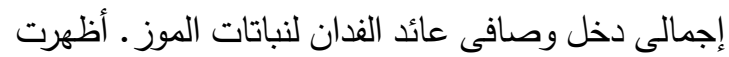

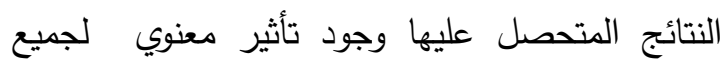

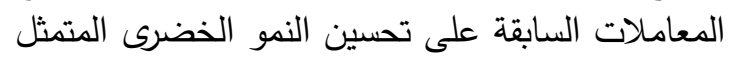

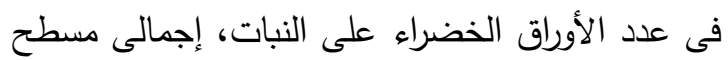

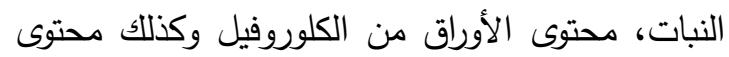

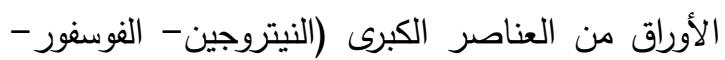
البوتاسيوم \%) ومحتوى الأوراق من العناصر الصغرئ الصنرى الصنئ

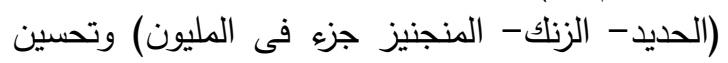

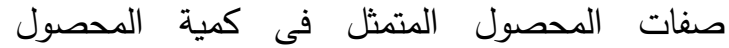

$$
\text { تحكيم: ا.د سعيد كمال عبدالنبي أحمد التهامي على التهد }
$$

